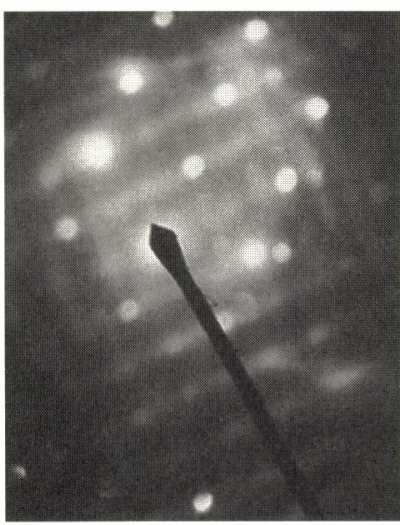

\title{
マイクロマシンの光デバイスへの応用
}

Micro-machines Application to Optical Devices

\section{上西 祐司*}

\section{1.はじめに}

電子回路がトランジスタの発明とともにLSI 化の道 を辿り, 半導体レーザ ( $\mathrm{LD})$ の出現により光デバイス の集積化が進展してきた。さらに現在, 機構部品の LSI 化がマイクロマシン技術として実現し，その研究開発が 精力的に行われている。

マイクロマシンは，LSI 技術を用いて文字どおり微小 機械をウェ八上に実現しようとするものである。シリコ ン（Si）を用いてマイクロ機構部品を作製する試みは, まず電子回路と同一ウェ八上に機構部品を集積化したセ ンサーを実現しようとする研究から始まった卢2)。

こうしたシリコンウェハ上への機構部品作製技術は マイクロマシニング技術と呼ばれ，パッシブな機構 部品のみならず，アクティブなマイクロアクチュエ 一夕も作製されるようになり，1980年代末に UCバ ークレイ大とマサチューセッツ工科大から静電マイ クロモー夕が相次いで発表され ${ }^{3), 4)}$ ，マイクロマシ ン研究ブームが訪れ，これまでにさまざまなタイプ のマイクロマシンが発表されている5 。

マイクロマシンは一般に発生力が小さく, その変 位量も高々数 $\mu \mathrm{m}$ と微量である。しかし，そのマ イクロなサイズと高精度な動きは微小な変位量が要 求される光波の制御には好都合である。同時に Si は LD などの光デバイス実装基板としても広く用い られており, 実装基板上にマイクロマシンを集樍化 することにより，各種光システム・モジュールなど
の大幅な小型化と多機能化, さらに低価格化が期待でき る。

本報告では，こうしたマイクロマシンを光デバイスに 応用した微小光機構デバイスとして, Si のバルクマイ クロマシニング技術で作製した微小光学素子およびニッ ケルマイクロマシニング技術で作製したマイクロミラー について紹介する。

\section{2.シリコンマイクロマシニングによる} 微小光学素子 ${ }^{6}$

水酸化カリウム $(\mathrm{KOH})$ 溶液を用いた（110）Si ウ

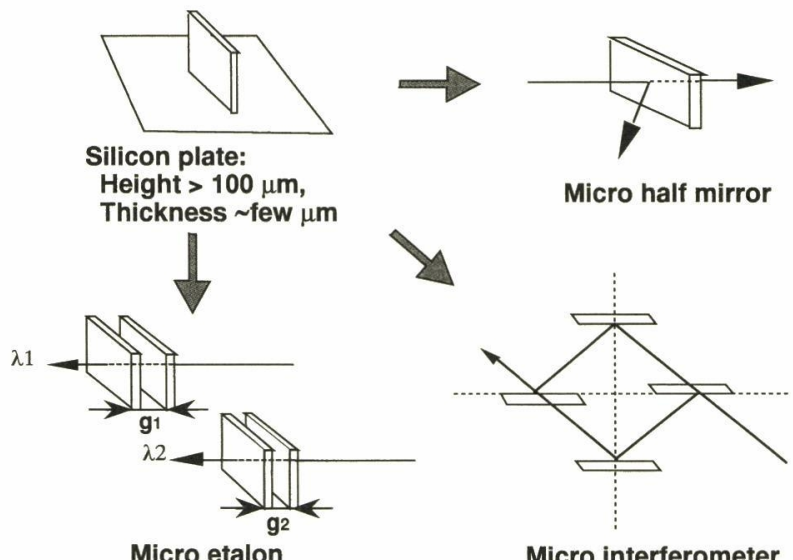

Fig.1 Silicon micromachined optical components for freespace micro-optics.

* Yuji Uenishi

日本電信電話(姝光エレクトロニクス研究所/Opto-electronics Research Laboratories. NTT

Vol.12, No.5 


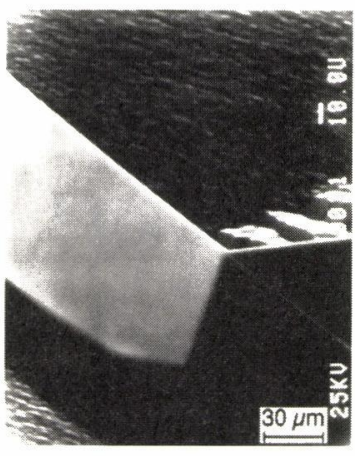

Fig.2 SEM photo of a high-aspect silicon plate.

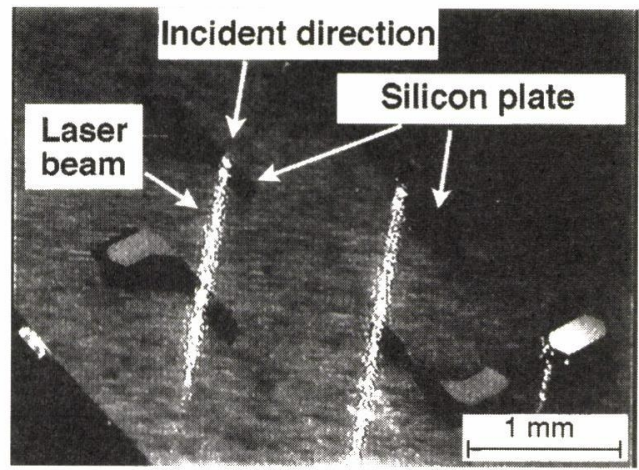

Fig.3 Micro Mach-Zehnder interferometer.

エハの異方性エッチングは他に類を見ないほどの垂直か つ高アスペクトな形状が得られ，そのエッチング側面で ある（111）結晶面は非常に平滑な面となる7),8 。この特 長を生かしてマイクロ素子としては比較的大面積 (100 平方ミクロン以上）な垂直鏡面を持つ $\mathrm{Si}$ プレートが作 製できる。このSiプレートは単独で，あるいはいくつ かを組み合わせることにより，Fig.1に示すようなフリ ースペース用の微小光学素子への応用が考えられる。こ

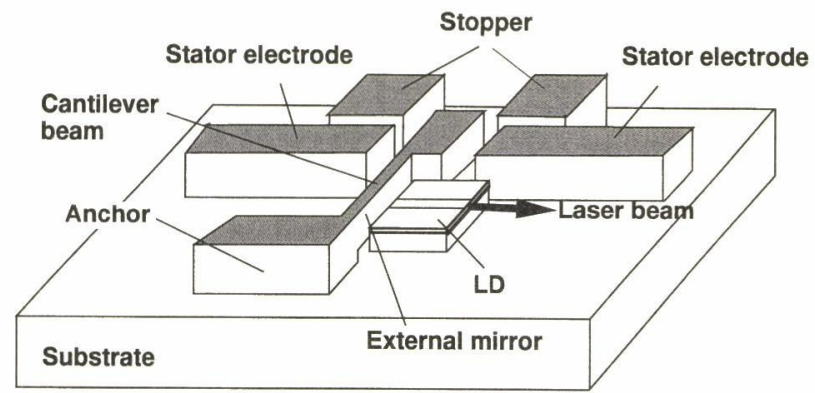

Fig.4 Schematic drawing of tunable laser diode with silicon micromirror.
れらのプレートの側面は全て結晶軸 $<111>$ 万向に揃っ ているため，完全な平行性を保っており，面倒な手動で の平行調整は不要である。このような平行性はエタロン などの光学素子においては大変重要である。

Fig.2 は作製した Si 基板上のハーフミラーの走査電子 顕微鏡 (SEM) 写真である。板厚は約 $1 \mu \mathrm{m}$, 高さは約 $200 \mu \mathrm{m}$ である。板厚が薄いため, 写真では向こう側の 構造物の稜線が影となって見えている。Fig.3 は Si プレ 一トをマッハ・ツェンダー干渉計状に配置したものであ る。1 枚の板の厚さは約 $7 \mu \mathrm{m}$, 高さが約 $150 \mu \mathrm{m}$, 長さ


様子が観察できる。

この（110）Si ウェハの異方性エッチングによる高ア スペクト加工により, たとえば $\mathrm{mm}$ オーダーの基板横 方向に柔らかい片持ち梁が作製でき，己の構造を利用し て低電压駆動の静電アクチュエータが実現できる。ここ では（110）Siウェ八の異方性エッチングに加之，Si と ガラス基板の静電接合技術を用いて夹現した LD 外部共 振器用静電駆動マイクロミラーを紹介する。

LD 実装した静電駆動型マイクロミラーの模式四を Fig.4に示す。長さ約 $1 \mathrm{~mm} の$ 片持ち梁を挟むように固 定電極ブロックが配置されている。この電極と可動梁と の間に電圧を印加することにより, 可動梁が静電力で曲 げられる。電極の上隣にはストッパーが設けられ，片持 ち梁と電極ブロックとが電気的にショートしないように している。この片持ち梁の (111) 側面が外部ミラーと なる。変位量が小さいので，ほほ LD 䢃開面に平行なま まミラ一面が駆動する。また，レンズを用いないため, LDはミラーに近接してボンディングする。

デバイスの SEM 写真をFig.5 に示す。可動ミラーで ある片持ち梁は長さ約 $1,200 \mu \mathrm{m}$, 幅 $8 \mu \mathrm{m}$, 高さ $130 \mu \mathrm{m}$ で, アクチュエータ電極間ギャップは7 $\mu \mathrm{m}$ である。ま

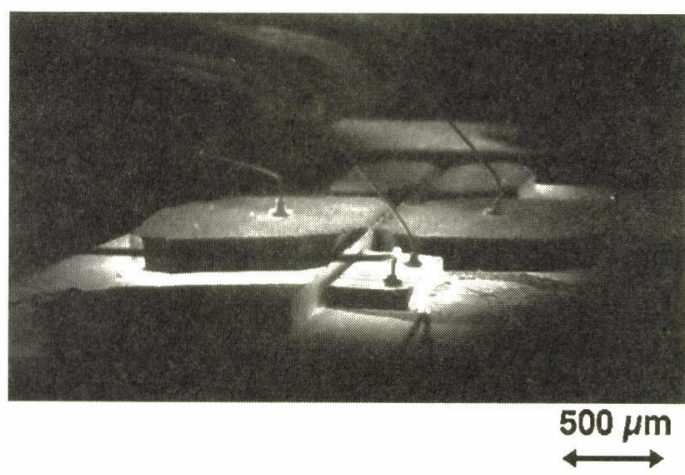

Fig.5 SEM photo of the tunable LD with silicon micromirror. 


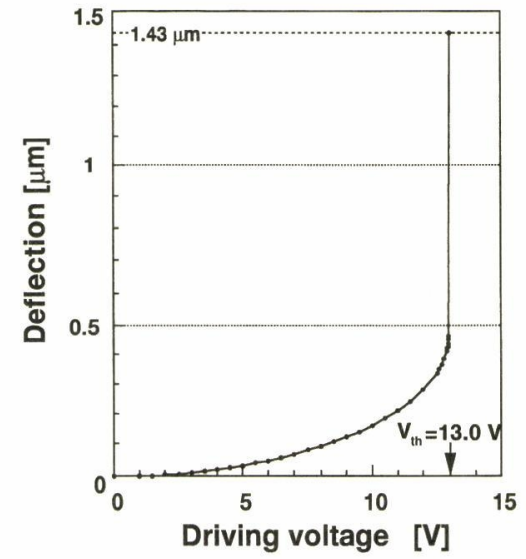

Fig.6 Si mirror deflection as a function of the driving voltage.

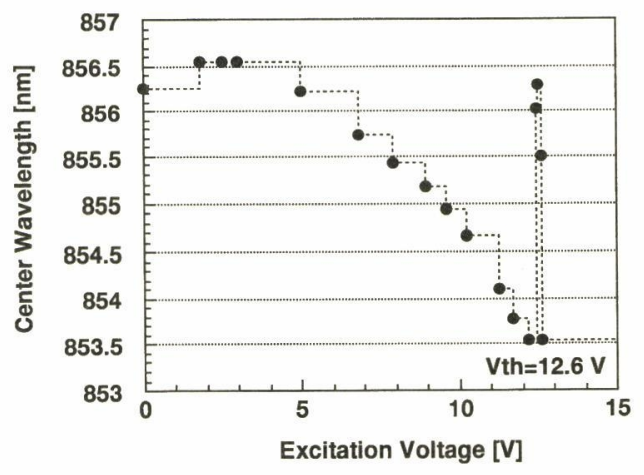

Fig.7 Wavelength tunability of the LD with silicon micromirror.

た，LD 端面と外部ミラ一面との距離は約 $10 \mu \mathrm{m}$ である。 マイクロミラー変位量と電圧との計算結果をFig.6に 示す。四は典型的な平板電極型のアクチュエー夕特性を 示している。LD 端面とミラーとの間隔である外部共振 器長の変分は $0 \sim 0.5 \mu \mathrm{m}$ の範囲で連続制御でき，電圧



Fig.8 Schematic drawing of the nickel micromirror.
がしきい電圧 $(\mathrm{V} t \mathrm{th}=$ 約 $13 \mathrm{~V})$ 以上になると静電力が急 激に増之，梁は電極に完全に引き付けられる。この時の 外部共振器長の変分は計算值で1. $43 \mu \mathrm{m}$ となる。

マイクロミラ一の変位に伴い LD 発振波長が変化する 様子をFig.7 に示す。ここでは LD 端面に無反射コート を施していないため，LDの両䢃開面で構成された共振 器長 $($ 約 $340 \mu \mathrm{m})$ で決まるファブリペローモード間隔 $(0.3 \mathrm{~nm})$ ごとの離散的な縦モ一ド変化が得られた。そ のトータルの波長可変範囲は約 $3 \mathrm{~nm}$ となった。 $0.3 \mathrm{~nm}$ ごとの波長選択が行えるので，外部ミラ一の変位精度と しては少なくとも40nm 以下と見込まれる。

\section{3.ニッケルマイクロマシニング技術による} マイクロ駆動ミラー

$\mathrm{Si}$ ウ土八表面上に微小光学素子を実現するためには, 基板表面と平行方向に走る光ビームを扱うのに十分広い 側面を持つ高アスペクトな構造体が必要である。めっき 技術はこうした厚膜を比較的容易に形成できる技術のひ とつである。めっき技術による構造体の作製法としては 基板上にレジストなどで鋳型を作製し，その鋳型にめつ き膜を堆積後，鋳型部分を取り除くという手法が一般的 である。さらに構造体となる金属が Si とどに比べ光学 的にも高い反射率が得られることから，ミラー系の微小 光学素子に適している。

$\mathrm{Ni}$ マイクロミラーの構成をFig.8に示す。ミラーは チップ中心部の先端にあり， $\mathrm{Ni}$ 梁(バネ) で両側に支 えられている。駆動部には櫛形電極を持つ静電駆動マイ クロアクチュエータ (10)を採用している。櫛形電極静電駆 動マイクロアクチュエータの特長は電圧の二乗に比例し た変位が得られ電圧制御が容易なこと，櫛の長さに見合 った変位が得られること，七ステリシスがないなどがあ げられる。

作製したマイクロミラーの SEM 写真をFig.9 に示子。

Vol.12, No.5

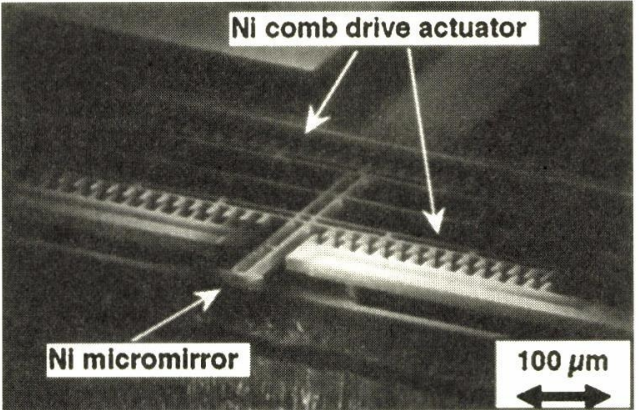

Fig.9 SEM photo of the nickel micromirror. 


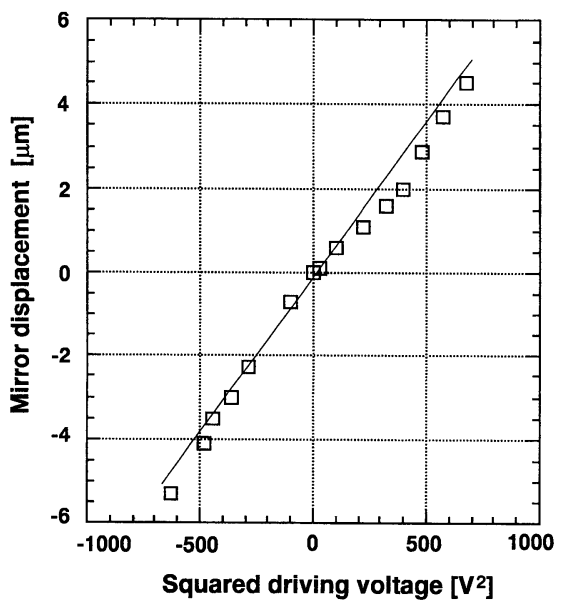

Fig.10 Ni mirror displacement as a function of the squared driving voltage.

ミラーの大きさは縦 $20 \mu \mathrm{m} \times$ 横 $50 \mu \mathrm{m}$, 梁の長さは全長 約 $1.5 \mathrm{~mm}$, 櫛の長さが $20 \mu \mathrm{m}$ である。ミラ一の変位特性 を Fig.10に示す。横軸が電圧の二乗でほぼこれに比例し た変位となり， $\pm 25 \mathrm{~V}$ で約 $10 \mu \mathrm{m}$ の変位量が得られた。 また，電圧を細かく制御することによりナノメートルオ ーダーの変位精度が見込める。

\section{4.まと め}

マイクロマシンの高精度な動きを積極的に光波制御に 応用した例として，Si マイクロマシニングによるフリ 一スペース用微小光学素子と $\mathrm{Ni}$ マイクロマシニングに よるマイクロミラーを紹介した。 $\mathrm{Si}$ 基板上に直接こう した光学素子を作り込むことにより光学系特有の細かい 光軸調整が不要になるだけでなく, 光システムとしての 集積度の大幅な向上と可動素子による多機能化が図れる。 今後の課題としては構造物の厚膜化, 高アスペクト化に よる大面積化，ミラ一面の平滑化，そして光学素子を制 御するアクチュエータの高性能化があげられる。

マイクロマシニング技術の登場により，Si が半導体 材料としてだけでなく, 機構部品材料, さらに光学材料
としてもその用途が広がりつつあり，文字どおり定盤の 光学系が全て指先に載るような $\mathrm{Si}$ 基板上の微小光学シ ステムの実現が期待される。

\section{参 考 文 献}

1) "Special issue on three-dimensional device structures," IEEE Trans. Electron Devices, Vol. ED-25, No. 10, (1978).

2) "Special issue on solid-state sensors, actuator, and interface electronics," IEEE Trans. Electron Devices, Vol. ED26, No.12, (1979).

3) L. S. Fan, Y. C. Tai, and R. S. Muller: "IC-Processed Electrostatic Micro-Motors," in Technical Digest, IEEE Int. Electron Device Meeting, San Francisco, CA, (Dec. 1988), pp. 666 669.

4) M. Mehregany, S. F. Bart, L. S. Tavrow, J. H. Lang, S. D. Senturia, and M. F. Schlecht: "A Study of Three Microfabricated Variable-Capacitance Motors," Transducer'89 (June 1989), 講演番号 B5. 3.

5）たとえば，「動くシリコンへ， Si マイクロマシーニング技 術」, 日経エレクトロニクス, 1989年 8 月 21 日号, No. 480, pp. 125 155 .

6) Y. Uenishi, M. Tsugai, and M. Mehregany: "Micro-optp mechanical devices fabricated by anisotropic etching of (110) silicon,” J. Micromech. Microeng., Vol. 5, (1995),pp. 305 312.

7) D. L. Kendall: "Vertical etching of silicon at very high aspect ratios,” Ann. Rev. Mater. Sci., (1979), pp. 373 403.

8) H. Seidel, L. Csepregi, A. Heuberger, and H. Baumgartel: "Anisotropic etching of crystalline silicon in alkaline solutions," J. Electrochem. Soc., Vol. 137, No. 11, (1990), pp. $3612 \sim 3626$.

9) Y. Uenishi, M. Tsugai, and M. Mehregany: "Hybrid-integrated micromirror of laser-diode fabricated by (110) silicon micromachining," Electroniocs Letters, Vol. 31, (1995), pp. 965 966.

10) W. C. Tang: "Laterally driven polysilicon resonant microstructures," Sensors and Actuators, Vol. 20, (1989), pp. $25 \sim 32$.

上西祐司 (うえにしゆうじ)

\section{〔執筆者紹介〕}

1984年, 大阪大学・工学研究科修上課程了。同年, 電電公社 (現NTT) に入社。現在, 光マイクロマシンの研究開発に従 事。IEEE，応用物理学会会員。 